\title{
SOCIAL CAPITAL AND MULTI-STAKEHOLDERS COOPERATION AS A FOUNDATION OF CORPORATE SOCIAL RESPONSIBILITY
}

\author{
Kafa Abdallah Kafaa \\ abdallah_kafa@mail.ugm.ac.id \\ Department of Social Development and Welfare, Universitas Gadjah Mada
}

\begin{abstract}
ABSTRAK
Beberapa hasil penelitian yang telah dilakukan telah menunjukkan bahwa masih banyak perusahaan yang menjalankan program CSR yang tidak lebih dari sekadar alat yang ampuh untuk memperbaiki dan membangun citra perusahaan yang baik bagi masyarakat. Dengan mengambil kasus pada Program Pendampingan Posyandu Pelawi Menuju Posyandu Mandiri, artikel ini akan menyajikan diskusi yang berbeda dan akan memberikan penjelasan mengenai fondasi yang mendukung bagi keberlanjutan program CSR. Penelitian ini menggunakan metode kualitatif dengan mengacu pada pendekatan studi kasus. Data yang diperoleh dalam penelitian ini didasarkan pada dua tahap, yaitu: wawancara mendalam dan observasi lapangan. Hasil penelitian menunjukkan bahwa modal sosial dan kerja sama multi-stakeholders telah dimanfaatkan dengan baik sebagai fondasi untuk menunjang keberlanjutan program beserta segala kegiatan di dalamnya. Namun, program tersebut juga tidak terlepas dari kritikan. Modal sosial yang digunakan dalam program cenderung berlebihan. Apabila penggunaan modal sosial yang berlebihan ini terus berlanjut, maka akan membuat Posyandu Pelawi menjadi ketergantungan. Meskipun demikian, dukungan sosial dari berbagai pihak juga sangat diperlukan untuk keberlanjutan program ini. Namun, kerja sama antar multi-stakeholders ini juga terkesan masih spontan dan belum secara khusus ditujukan untuk keberlanjutan program.
\end{abstract}

Kata kunci: corporate social responsibility (csr); kerjasama multi-stakeholders cooperation; modal social; program pendampingan posyandu.

\begin{abstract}
Refers to several studies that have been conducted, the results showed there are still many companies that run CSR programs does more than just as a powerful tool for development and improvement of the company image within the community. By taking the case on Program Pendampingan Posyandu Pelawi Menuju Posyandu Mandiri, leading to this study would be a different and more direct discussion on the explanation of the foundation that supports the sustainability of the program. This study uses qualitative methods with referring to a case study approach. Data obtained in this study is based on two stages, namely: in-depth interviews and field observations. The result shows that social capital and multi-stakeholders cooperation have been put to good use as a foundation of the sustainability program including its activities. However, the program is not free from criticism. Social capital used in the program tend to be exaggerated. When the use of excessive social capital persists, it will make Posyandu Pelawi dependency. Even though, as a preliminary, social support from various parties is very necessary for the Program. The goal efforts of achievement Program from stakeholders are still spontaneity and not specifically.
\end{abstract}

Key words: corporate social responsibility (csr); multi-stakeholders cooperation; program pendampingan posyandu; social capital.

\section{INTRODUCTION}

Corporate Social Responsibility (CSR) as a conceptual and practical framework have received significant attention in recent years
(Jones at al., 2009; Ramasamy and Yeung, 2010). This is happened particularly in most developing countries which the ownership and pace of business dictated by Multi- 
national Corporation (MNCs), so there have been increasing demands on enterprises to provide community and environment development programs that occurred in operational-located businesses (Hensen, and Ndhlovu, 2011). Also, the discussion of related CSR in the area of scholarship in Indonesia as one of the developing countries has been done in any progress. The results of the CSR discussion are still many dwelling on the debate between the discourse and the CSR theory, CSR idealism with realities in the field (Susetiawan, 2012), and repeated the definition of CSR through offered alternative concept (Yuda, 2016). However, the undeniable fact that was found in the practice of CSR is often used as a powerful tool for development and improvement of the company image or in the public space (Suharto, 2008); as a key driver of corporate reputation in terms of employee relations, community engagement and environmental improvement issues (Melo and GarridoMorgado, 2011).

Thus, made the State of Indonesia sets up in such a way that the practice of Corporate Social Responsibility (CSR) agenda-oriented is not only companies profit-oriented, but also an embodiment of effort-oriented social life and a better environment in accordance with the potential, problems, and opportunities. In Indonesia, CSR does not only refers to social issues but also the question of the environment. It would have been poured into the Act of the Republic of Indonesia Number 40 of the year 2007 on Limited Liability Companies Article 74 about the Social and Environmental Responsibility (TJSL). Social and environmental responsibility is the company's commitment to participation in sustainable economic development in order to improve the quality of life and the environment, good for the company's own self, the local community, and society as a spacious.

Basically, Indonesia requires that for every company operate in the region of Indonesia to run a CSR or Social and
Environmental Responsibility (TJSL), especially for companies associated with the exploration and production of natural resources (Law No. 40 of the year RI 2007 Article 74 Paragraph 1). Any practice of TJSL will be judged in the Company's Performance Rating Program (PROPER) as set forth in the regulation of the Minister of State for the environment No. 5 the year 2011. A PROPER assessment will generate a ranking of companies, which refer to the lowest rank (black predicate) and highest (gold predicate).

Furthermore, it is possible for a company to do a study related the identification of the potential, problems, and opportunities that exist in the target area CSR programs. Wibisono has provided an overview of the region mapping for the CSR implementation, namely: Ring I is directly (0-500 Meter from the assets of the company); Ring II is a potentially affected zone directly (501-1000 Meter from the assets of the company), Ring III is not directly affected zones (1001-1500 Meter from the assets of the company), and; Ring IV is not directly affected zones (over 1500 Meter from the assets of the company) (Wibisono, 2007: p. 140). Related to this data, I have been doing related research on the CSR programs undertaken by PT. Pertamina EP Asset I Field in Kampung Suka Jadi village, Rantau Sub-District, Aceh Tamiang Regency (Ring I). The CSR program was named the Program Pendampingan Posyandu Pelawi Menuju Posyandu Mandiri.

The article will strive further an idea of the associated capital strength social communities and roles between stakeholders in its efforts. Also this is in line with the function of social capital that can become a social or community setting influences the adoption and community and environmental development within CSR practices (Jin and Shriar, 2013; Kusakabe, 2012; Thoyre, 2011). This is because the social capital embedded in community so the groups and individuals provide information that enriches their ability to cope and make the CSR program sustainable (Gupta and Ogden, 2009). 
Likewise, the CSR program also need to occur the collaboratory system that allows the other institution to implement the program together as multi-stakeholders cooperation (Allinson et al., 2012; Kania and Kramer, 2013; Mortensen, 2012). Any related research mapping of roles between stakeholders cooperation in the CSR program in Indonesia such as this does not become the first. Krisdyatmiko in the results of his studies stated that the creation of multistakeholders forum and the local regulations that were initiated by the Government has provided a positive turning point for the development of East Kutai Regency, East Kalimantan (Krisdyatmiko, 2012). In contrast to such research, CSR programs taken in this study is an initiation result of the company parties then followed with the role of other stakeholders.

This article does not explain in the realm of the success of the program, but rather the implementation process of on the Program. Then the author basing the study on the question, how does the social capital exist in the Kampung Suka Jadi, whose support for the sustainability of the program, and how existing stakeholders in the achievement the purpose of the program is. This article has been considering many research-related CSR programs that generate the CSR program that does more than just development and the company's image or improvement. Then this article will strive to further deepen and directed on discussion background programs that support for the process towards the success of the program.

\section{THEORETICAL FRAMEWORK Social Capital}

The theory of social capital has been the focus of discussion, research and development in various development policies especially inspired by Robert D Putnam's works such as; Making Democracy Work: Civic Transition in Modern Italy, 1993, and Bowling Alone: America's Declining Social Capital, 2000. Likewise with Francis Fukuyama with his work The End of History and
The Last Man, 1992; Trust, The Social Virtues and The Creation of Prosperity, 1995; The Great Disruption, Human Nature and The Reconciliation of Human Order, 1999; Social Capital and Civil Society, 1999; Social Capital and Development: The Coming. 2002, and several other works.

When viewed from its definition, social capital is something that refers to the institutional dimension, relations created, and norms that shape the quality and quantity of social relations in society (Woolcock and Narayan, 2000). Cohen and Prusak (2001) also explain that social capital as a stock and an active relationship between communities. Every pattern of relationship that occurs is bound by mutual trust and shared values that bind group members to make possible joint actions that can be carried out efficiently and effectively.

According to other theorists, social capital is defined as a representation of human resources, because it involves the expectation of reciprocity, and goes beyond any individual so that it engages in a wider network whose relationships are governed by high levels of trust and the application of norms. shared norms and values (Coleman, 1999). Thus, in this article, the discussion will refer more to the social capital theory proposed by Coleman. Based on Coleman's statement, there are some important things that must be observed especially in relation to social conditions in society, including; Participation, reciprocity, beliefs, social norms, shared values and proactive actions.

Participation in a network is the key to success in building social capital. Also lies the ability of a group or network in a pattern of social relations. Human are social creatures, which means that human always interact with other human. These interactions can take various forms that are adapted to the situation and condition of the community, then create a pattern of social relations. Social relations are always based on the principles of volunteerism, equality, freedom, and civilization. The ability of social relations has a great influence on 
determining the strength of social capital itself.

Social capital is often characterized by a tendency to exchange the goodness between individuals in a group or groups with other groups. This pattern of exchange is not something done reciprocally as in the process of buying and selling, but a combination of short-term and long-term in the spirit of helping and prioritizing the interests of others (altruism). Reciprocity is closely related to the issue of trust. The desire to take risks in social relationships is always based on feeling confident that others will do things as expected and always act in a pattern of actions that support one anothers (Putnam, 2000).

Behavior in social relations will never be separated from the norms prevailing in society. So that the more intense social relations in a society, indirectly these social relations have the binding power of individual behavior. This is because there are norms that are usually institutionalized and contain social sanctions for anyone who violates. Likewise, the values prevailing in society. One important element in social capital is the strong desire of each individual member in the community to not only participate, but to find a way for their involvement in society actively and creatively.

Thus, in relation to CSR programs, social capital will be one of the important factors that can build and support sustainability of program. If participation, reciprocity, beliefs, social norms, shared values and proactive actions are created well in the community, CSR programs will actually be greatly assisted in their implementation.

Given the important things in social capital will determine how the cooperative relationship between the beneficiaries and the providers of their CSR programs. Therefore, it can be said here that CSR programs are supported by strong social capital in the community or its beneficiaries, so the program will be implemented well and sustainably.
Corporate Social Responsibility and Multistakeholders Cooperation

Corporate Social Responsibility (CSR) is a form of effort and commitment on an ongoing basis by the business community to contribute to the economic, social and environmental development agenda, both for the business entity itself, the government, the community, and the environment in which it operates. Through CSR, businesses are committed not only oriented to the acquisition of profit maximization as its spirit but also to build social, economic and regional environment holistically, institutionalized and sustainable (Suharto, 2007). According to Wibisono (2007), CSR practices have at least four benefits, both from the point of view of companies, governments or countries, communities and the environment. The four benefits are as follows:

1. For companies, such as: First, the existence of a company can grow and develop in a sustainable manner and get a positive image from various other stakeholders. Second, it is easier for companies to gain access to capital. Third, companies can maintain quality human resources. Fourth, companies can improve decisionmaking on critical matters and facilitate risk management.

2. For the government or the State, good CSR practices will certainly prevent Corporate Misconduct or business malpractice, such as bribery to the State apparatus or to law enforcement officials that trigger corruption.

3. For the community, the presence of companies in an area will absorb labor and improve the socio-economic quality of the people in the area.

4. For the environment, CSR practices will prevent over-exploitation of natural resources and of course maintain environmental quality.

In its implementation, CSR practices will be better if the whole process involves existing stakeholders. The definition of stakeholder itself refers to individuals, groups, or institutions that can influence and 
or are influenced by certain organizational entities as a result of their activities (Freeman, 1984). In the context of this discussion, corporate social responsibility is not only addressed to its owners or shareholders, but also to the parties (stakeholders) involved and or affected by the company's activities, which in this case is CSR practice.

Therefore, it is important for companies to consider and involve stakeholders in their CSR practices. This is what is called multistakeholder cooperation. The intended cooperation is an inter-sectoral agreement where individuals, groups and institutions agree to work together to fulfill an obligation or carry out an activity, jointly bear all risks and obtain benefits, and conduct a review of the process of implementing the cooperation itself periodically (Tennyson, 1998).

In this context, the practice of cooperation is intended to strive for the achievement of what has been the goal of the existence of CSR practices. Moreover, the achievement of the objectives of CSR practices will in turn touch upon the nature of CSR practices themselves, namely sustainable social, economic and environmental development. The CSR partnership that is built must also be guided by a productive partnership pattern. Such a pattern places partners as subjects and the implementation of a symbiotic mutualism process. The company has high social and environmental concerns, the government provides a conducive climate for business affairs, and the community as well as NGO provides positive support to the company.

\section{RESEARCH METHOD}

This study uses qualitative methods is referring to a case study approach. Methods of qualitative is research that has traits such as rooted in a natural setting as a wholeness; relying on human beings as research tools; utilizing qualitative methods; relying on analysis of inductive data; redirect targets its research efforts on finding a base; are descriptive; more concerned with process than results; limiting the study with focus; and has a set of criteria to check the validity of the data (Moleong, 2007: p. 6). While the approach of case studies is intended to describe a case, which refers to a person, group, organization, or event (Hair, et al., 2007: p. 203), which in this case is the Program Pendampingan Posyandu Pelawi Menuju Posyandu Mandiri in Kampung Suka Jadi Village, Rantau Sub-District, Aceh Tamiang Regency, Nangroe Aceh Darussalam (NAD) Province.

Data obtained in this study is based on two stages, namely: in-depth interviews and field observations. First, researcher observed the conditions on the ground. The following program by specifying the informant in order to proceed at this stage of the in-depth interviews. This observation is carried out directly in the field on December $23-27^{\text {th }}$, 2017. Second, researcher interviewed informants who have previously determined in advance based on the results of field observations. Determination of the informant is based on purposive sampling technique. Purposive sampling is the technique of data retrieval with certain considerations, for example, the person is considered the most knowledgeable about what expected (Sugiyono, 2012: p. 208).

Based on the purposive sampling technique, the informants chosen by researcher to determine among other things: Datuk Penghulu Kampung Suka Jadi (a chief of village); Imam Balai (head of Mukim Balai); the Council of Sapta Jaya; Head of Affairs (Kaur) Kampung Suka Jadi; Tok Imam (prominent figure of community) Kampung Suka Jadi; Founder of Posyandu Pelawi; Chairman of Posyandu Pelawi; Secretary of Posyandu Pelawi; Chairman of Welfare Development for Family (PKK); Treasurer of the Welfare Development for Family (PKK); Chairman of Child Development and Family (BKB); Secretary of Child Development and Family (BKB); Chairman of Progam Pendampingan Posyandu Pelawi Menuju Posyandu Mandiri group; Secretary of Progam Pendampingan Posyandu Pelawi Menuju Posyandu Mandiri group; Com- 
munity Development Officer (CDO) of PT. Pertamina EP Asset I Field Rantau; CDO of PT. Mopoli Raya; and staff of NGOs of Assessment, Empowerment, and Consulting Agency (LP2K).

Subsequently, the researcher has interviewed the informants on December 28 th, 2017 until January $4^{\text {th }}$, 2018. Data obtained are then analyzed using data reduction techniques, presentation of data, and the withdrawal of the conclusion. Then any existing data in the re-examine with the technique of triangulation based on sources, methods, and researcher (non-triangulation). It aims that the data shown on the results of the research are objective in accordance with findings in the field.

\section{RESULT AND DISCUSSION}

A Brief Profile of Kampung Suka Jadi and Posyandu Pelawi

Suka Jadi is a village located in Rantau District, Aceh Tamiang Regency, Nangroe Aceh Darussalam (NAD) Province. Almost all areas of Kampung Suka Jadi are planted with oil palm. In the Kampung Suka Jadi area, there are 2 large companies operating, namely PT. Pertamina EP Asset 1 Field Rantau and PT. Mopoli Raya. The operation of PT. Pertamina EP Asset 1 Field Rantau is in the field of petroleum exploration, while PT. Mopoli Raya is in oil palm plantations. On the other hand, Suka Jadi is also one of the villages under the auspices of Mukim Balai and Sapta Jaya. According to the Qanun (statutory regulation) of Aceh Tamiang District Number 13 of 2010, Mukim is a legal community unit under the sub-district consisting of a combination of several villages that have certain territorial boundaries led by a head of a mukim and domiciled directly under the sub-district head.

The Mukim's functions are among others: to implement Islamic law, to maintain harmony in religious life and between religious communities and the life of customs and traditions; to coordinate development to improve the welfare and life of democratic justice; to foster and oversee implementation in the fields of education, socio-cultural context, protection of basic rights, peace and order of the community and; to mediate and resolve disputes in the community based on customary law provisions. While Sapta Jaya is an informal alliance or binding of seven villages, including; Suka Jadi Village, Suka Rahmat Village, Suka Mulya Village, Labur Jamur Village, Jelatung Mushroom Village, Suka Rakyat Village, and Suka Jaya Village. Sapta Jaya was established in 1982 based on the agreement of the Village Heads and community leaders from the villages. The initial purpose of the establishment of Sapta Jaya was none other than to unite the seven villages, bearing in mind that in 1970-1981 in the Sapta Jaya region there were many conflicts and fights between residents of these villages.

Also, the existence of Sapta Jaya aims to spearhead progress in seven villages, bearing in mind that these villages are classified as disadvantaged villages when they are still in the territory of East Aceh Regency. However, after the regional expansion, the villages entered Aceh Tamiang Regency. At that time, Sapta Jaya functioned as a "political vehicle" to the seven villages in the delivery of aspirations and interventions to the Aceh Tamiang District Government. Until the writing of this article was completed, Mukim Balai and Sapta Jaya still existed and proceeded as they should be.

Besides being a form of union of the seven villages, Sapta Jaya is also known as an alliance or association of high achieving villages. One of them is Kampung Suka Jadi who won $2^{\text {nd }}$ place in the National Clean and Healthy Behavior Competition (PHBS) in 2010. Moreover, Kampung Suka Jadi through Posyadu Pelawi also won $1^{\text {st }}$ place for Best Posyandu in Aceh Province in 2012; $1^{\text {st }}$ winner in the Best Posyandu Cadre in Aceh Tamiang District 2012; and $1{ }^{\text {st }}$ winner of the Best Village Midwife in 2012.

Posyandu Pelawi was established in 1980 on a community self-help basis supported by the Kampung Suka Jadi Government. 
In terms of the implementation, integrated public health services which are the main activities of Posyandu Pelawi are held every third Wednesday every month. There are eight cadres owned by Posyandu Pelawi. Initially, funding for the implementation of the Pelawi Posyandu activities was based on community self-help funds through recitation groups. The Pelawi Posyandu cadres were not given severance pay or wages in their implementation, they did so based on volunteerism for the sake of public health. However, after the existence of the Village Fund from the National Budget (APBN) since 2015, the implementation of the Posyandu Pelawi activities was also more or less assisted by the Kampung Suka Jadi Government, especially in the procurement of Posyandu facilities and the provision of severance for cadres worth Rp. 50,000 per person per month. However, this did not stop the self-funding from the community, instead it increased the motivation of the community to pay for the self-help funds to improve the quality of health services from the Posyandu Pelawi. Moreover, with the myriad achievements of Posyandu Pelawi, the community and various institutions are increasingly interested in developing Posyandu Pelawi.

\section{Social Capital in Kampung Suka Jadi}

In terms of discussing the Program Pendampingan Posyandu Pelawi Menuju Posyandu Mandiri would be more interesting if we start with the social conditions of Kampung Suka Jadi. The social condition referred to social capital that exists in the community. Social capital is a part of the social life, which is set of norms and values, network, and beliefs that encourage individuals from communities to act together more effectively and efficiently in order to achieve the objectives along.

"In this case, social capital refers to the section of the social organization, such as trust, norms, and networks, which can improve the efficiency of society by facilitating coordinated actions." (Putnam, 1993: p. 167).

This social capital enables the existence of reciprocity, which refers to the feeling of obligation to help others as others have helped. Principally, the membership network, a set of shared values (Field, 2010: p. 5), trust, and reciprocity (Putnam, 2000: p. 19) is the core of social capital on. Therefore, the social capital heeded good relationships among the individuals of society. This part will explain how the social capital of the community have built up long enough and strong as a tradition rooted in the form of Gotong-royong. In the context of Kampung Suka Jadi, it can be said that social capital has built long enough and entrenched. This reflected one of how the community members help each other to create a harmonious social condition, in the embodiment of the welfare of society as a whole. Although economically the Kampung Suka Jadi community is still on the poverty line, that does not deter for them to help others. This assistance is reflected in the form of financial, effort, time, and mind.

Gotong-royong is the most suitable term to describe how social capital in the Kampung Suka Jadi it grows and develops. Gotong-royong means a form of action which refers to the principle of helping each other (Seavoy, 1977), moral obligation and reciprocity (Bowen, 1986), and a collective action. In other terms, Gotong-royong is informal welfare provision (Sumarto, 2017). On the Kampung Suka Jadi social conditions, Gotong-royong as a manifestation of social capital can be traced in two form, namely as an act together, and as a financial assistance.

First, the activity can be seen from the presence of volunteerism in all its activities to be beneficial for collective and for other individuals or families. In terms of collective beneficial, there is Talud activity within infrastructure development of Kampung Suka Jadi. At the time this research was conducted, there were activities in terms of Talud retaining walls in a landslide a 
prominent mosque community. The workers working on the Talud comes from the men who were the community of Kampung Suka Jadi.

On the other side, women were working are not in the domain of Talud development directly like men, they prepared food and beverage for men. The interesting thing in this activity that is they worked without asking for or wages over the activities. They do something on a basic of voluntary and beliefs in their community, by the community, and to the community. Although it cannot be denied that, there are some people who are given a fee for such activities. They include the contractors, the architecture, supervisor, the specialist workers, and default workers. On the other hand, the activity is too beneficial also seen from how each element of the community's efforts in realizing a clean and healthy environment. This activity is carried out from the year 2009-2010 in order to confront the Competition of Clean and Healthy Living Behaviour (PHBS) in 2010. All of the community clean up homes, yards, sewers, roads, and gardens of palm oil, which is the access way to Kampung Suka Jadi. The community based on the purpose of beneficial perceived together. In addition to preparing for the pageant contest, hygiene, and environmental health is also very beneficial to the community.

Through to the end and a long process, Kampung Suka Jadi won the second winner of that competition. The interesting thing is the principle of volunteerism that has always been the foundation on any Gotong-royong. Although no form of appreciation gave the Government toward Kampung Suka Jadi achievement as the second winner, the community still feels good due to the healthy and clean environment. Although it cannot be denied that, there was, also disappointment over the absence of difficulties over predicates the championship.

The same thing also looks at the dynamics of the development Posyandu Pelawi. The cadre is representative of community agreements and results in carrying out its work as a maid and integrated healthcare provider did not escape from the principle of volunteerism. The number of cadres of Posyandu Pelawi currently as many as eight people. Then be included eight people of BKB cadre in order to accompany the Posyandu Pelawi activities. This is base of the basic tasks and functions in line with its own Posyandu Pelawi.

The cadres within the implementation of healthy integrated services were doing with capabilities on their duty. Posyandu Pelawi can see this in the improved quality of cadres in the integrated health services, increase public awareness of the importance of health, and a variety of achievements. Once again, the cadres are not given salary or wages at all in any of its activities.

In the activity of which is too beneficial individuals or other families, there are Gotong-royong homebuilding, construction of stalls, and assistance on any custom event (weddings, circumcision, and ceremonial thanksgiving). Usually, every head of families comes and helps in the whole event. It runs continuously and sustainable due to the principle of reciprocity and volunteerism that have been awakened in Kampung Suka Jadi community. So it is heeding a social capital manifested themselves in the form of an obligation morally.

Second, the activity can be seen from the existence of the Dasa Wisma Group and the Recitation Group. Dasa Wisma is a group established based on the instruction of the Kampung Suka Jadi Government, which consists of 10 until 13 houses. There are 14 group Dasa Wisma in Kampung Suka Jadi. Grouping Dasa Wisma is based on proximity distance between the houses and chaired by one person based on mutual agreement. The task of the chairman Dasa Wisma is to draw on the members of his group dues amounting to IDR 2.000 per month with details of IDR 1.000 to social and death fund, and IDR 1.000 to Posyandu Pelawi fund. The magnitude of the contribution funding is the result of a mutual agreement of community. 
On the function of the Dasa Wisma is divided into two, namely the function as instruments of social funds and death for members of groups and self-help funds for contracting functions of Posyandu Pelawi.

The quantity funds given to each person who died was valued at IDR 100.000 who later managed and allocated for food supplies for the mourners. Dasa Wisma also serves as a giver and service dealer needs food for mourners who visited the funeral home.

The Dasa Wisma's total funding contribution result collected to the treasurer of the Welfare Development for Family (PKK) later managed and distributed to the Dasa Wisma in case of the death of members of the group.

Table 1

Total of Accumulation of Dasa Wisma Fund and Total Expending for Social and Death and Posyandu Pelawi Funds

\begin{tabular}{cccc}
\hline \hline Year & $\begin{array}{c}\text { Income from Dasa } \\
\text { Wisma (IDR) }\end{array}$ & $\begin{array}{c}\text { Fund Expending for Social } \\
\text { and Death (IDR) }\end{array}$ & $\begin{array}{c}\text { Fund Expending for } \\
\text { Posyandu Pelawi (IDR) }\end{array}$ \\
\hline 2015 & 3.407 .000 & 1.280 .000 & 1.200 .000 \\
2016 & 3.910 .000 & 1.755 .000 & 1.800 .000 \\
\hline
\end{tabular}

Source: Obtained from Primary Data, 2017.

When there is a shortage of funds from one Dasa Wisma, then cross-subsidies will be done from another Dasa Wisma. Also, the Dasa Wisma often funding from any the groups used to help certain events, such as the great religious event (Mawlid Nabi, the anniversary of Nuzulul Qur'an) and major events, such as the State independence of the Republic Memorial Indonesia on August 17.

While the second function i.e. Dasa Wisma as contracting funds self-helping to develop Pelawi Posyandu. These funds are derived from the community contribution withdrawal done by Dasa Wisma. The magnitude of the funds withdrawn in dues is IDR 1.000 per month at each house. The funds will be collected and maintained in advance at the Welfare Development for Family (PKK) and then submitted to the Posyandu Pelawi on every end of the month. The funds collected will be spent to support the activities of integrated community health services principal held on the third Wednesday of each month. Usually, these funds used to buy the ingredients making porridge toddlers and babies who are then given away free to participants, purchase of medicines and consumables, as well as consumption for midwives, medical personnel, and Posyandu cadre of its own. In terms of Recitation Group, the mechanism of financially lies in withdrawal dues payroll group member suddenly. For example, if there is a member of illness until the required medical treatment to the hospital, then the Recitation Group in activities will require some donations. Even though there is a member of the Recitation Group that gave birth in a hospital, then a group recitation will help financially. Basically, if there is Recitation Group's member who suffered an accident and required medical treatment to the hospital, and then Recitation Group will always help especially in terms of financial.

Also, this Recitation Group was divided into three groups based on Hamlet, namely Dewi, Sinto, and Sari. On the contrary, the division of the Recitation Group based on gender, i.e. fathers (male) and mothers (women). The Recitation Group activities for fathers (male) held every Thursday night and for mothers (women) held every Friday night. Furthermore, for adolescents and young adults, Recitation Group have not grouped by gender and Hamlet but made one group of study. While the Recitation Group activities for teens and young adults have the Recitation Group was held on 
second and fourth Friday night in one month. Moreover, there are also financial death assistance for a member of the Recitation Group and his family. Such assistance in the form of relief food and drinks consumed when unsettled Tahlilan activities for three consecutive days after the day of death. Funds for the assistance obtained from the withdrawal of contributions from each house which coordinated by the head of the hamlet. The results of these donations are then spent on groceries for the next managed and distributed to each person who is present in the Tahlilan.

The Foundation of Program Pendampingan Posyandu Pelawi Menuju Posyandu Mandiri

Social capital through events or traditions Gotong-royong explained in advance is extremely complex, not in spite of the challenges that exist in it. One of the challenges of the social capital on is how it can be a foundation for the sustainability of the Program Pendampingan Posyandu Pelawi Menuju Posyandu Mandiri. If viewed from the history of the appearance of the program, it could not be denied when PT. Pertamina EP Asset I Field Rantau initiated its appearance.

However, it is also not strictly regardless of how the functions of the social capital that have been awakened in the community. This section will explain how the social capital that exists in the Kampung Suka Jadi community, then became a foundation for the sustainability of program. The Program Pendampingan Posyandu Pelawi Menuju Posyandu Mandiri is conducted by the due fulfillment of corporate social responsibility towards the territory becomes the company operation. In this case, Kampung Suka Jadi is one of the regions oil drilling by PT. Pertamina EP Asset I Field Rantau. Therefore, PT. Pertamina EP Asset I Field Rantau should do the social responsibility of the company to Kampung Suka Jadi. On the other hand, is also based on predicate earned by Kampung Suka Jadi as champion 2-year 2010 National PHBS, Posyandu Pelawi as Posyandu Best Aceh Tamiang Regency year 2012, Best Posyandu Cadre Aceh Tamiang Regency year 2012, and Best Village midwife Aceh Tamiang Regency of the year 2012. So the more allure Posyandu Pelawi to progressively develop through CSR programs of PT. Pertamina EP Asset I Field Rantau.

This Program strives to provide containners for the Posyandu Pelawi in order to produce healthy funds independently as an indicator toward Posyandu Mandiri. Currently, the Posyandu Pelawi still occupy the level of Posyandu Purnama. Therefore, this program has three events, namely the Cultivation of Mushrooms, Making Herbal Beverage, and the Trash Bank. These activities are expected to be a way to raise funds for the Posyandu Pelawi.

Table 2

Level of Posyandu

\begin{tabular}{|c|c|c|}
\hline No. & Strata & Criteria \\
\hline 2013 & $\begin{array}{l}\text { Posyandu } \\
\text { Pratama }\end{array}$ & $\begin{array}{l}\text { The activities is not routinely, less than five cadres, low scope } \\
\text { services }\end{array}$ \\
\hline 2014 & $\begin{array}{l}\text { Posyandu } \\
\text { Madya }\end{array}$ & $\begin{array}{l}\text { The activities more than eight per year, more than five cadres, low } \\
\text { scope services }\end{array}$ \\
\hline 2015 & $\begin{array}{l}\text { Posyandu } \\
\text { Purnama }\end{array}$ & $\begin{array}{l}\text { The activities more than eight per year, more than five cadres, } \\
\text { middle scope services, low independency health budget }\end{array}$ \\
\hline 2016 & $\begin{array}{l}\text { Posyandu } \\
\text { Mandiri }\end{array}$ & $\begin{array}{l}\text { The activities more than eight per year, more than five cadres, } \\
\text { middle scope services, high independency health budget, extra } \\
\text { activities implementation }\end{array}$ \\
\hline
\end{tabular}


The Mushroom Cultivation activity was a replication of the program from the Suka Ramai village who is also one of the village's small-scale CSR programs of PT. Pertamina EP Asset I Field Rantau. The activity of making herbal beverage or herbal medicine is the government and the request of the community did in the sustainability of the training, especially the cadres themselves. Then, the bank of trash is the sustainability of the program that has been implemented by the NGOs LP2K in the year 2015.

The activities of mushrooms cultivation, making herbal drinks, and trash bank were activities of Program, which is implemented at Kampung Suka Jadi. The third activity is managed in groups under the auspices of the Welfare Development for Family (PKK) and Posyandu Pelawi. Beneficiaries while the administrators in these programs are cadres of Posyandu Pelawi, Child Development and Family (BKB), and Welfare Development for Family (PKK). The members are people who have been trained by various kinds of training, whether it was implemented by the government as well as by PT. Pertamina EP Asset I Field Rantau.

Program execution is also deriving from social capital in the community. It is not only in terms of financial assistance as mentioned above, but there is a strong social capital in supporting the sustainability of the program. Else the principle of reciprocity and volunteerism who became the spirit of this program. In order to explain how the interconnectedness of social capital with the program, then authors divide it into three kinds of activity, i.e. the activity of making an herbal beverage, the cultivation of mushrooms, and the trash bank.

First, on the activity of making an herbal beverage, there is highly enthusiasm of the members. This can be seen from how the members always comply with the schedule of implementation activities every Saturday. Rarely found the existence of the absence of this activity, unless there is an urgent affair and cannot be left out. Overall, the members of the group have always tried to be present at the execution of this activity. This is due to the presence of feeling bad when they do not come on such activities without any affair that really urgent. On the other hand, there are also feeling glad of every member will be making this herbal beverage activity. Even though a majority of the members thought that, this activity is a form of recreation.

Products produced in this activity is the Red Ginger Herbs and Bandrek. This activity was originally trained and accompanied by a companion technical and Community Development Officer (CDO), but over time, these activities take place independently managed directly by the group. Currently, these herbal beverage product sales have been sold over the counter, even to accept orders from outside parties. This is one of them caused by marketing on a voluntary basis from each element of the community, start from the stalls that exist in the village, to relatives or their family. Until the research is completed, the product marketing is still on the rising up.

Second, on the activity of mushroom cultivation, the group's enthusiasm is high. Although the program does not originate from the demand of the community. In addition, there is a mechanism in the management of passes; the group members strongly support the sustainability of these activities. This can be seen from how their volunteerism when the Manager is facing an obstacle and cannot to manage the mushrooms, members will voluntarily and take turns to replace him. The whole management of cultivation mushroom consists of home cleaning every morning, harvest and granting of the baglock. Those members who succeeded the temporarily was implementing it based on volunteerism.

Products produced in this activity are still in the form of bulk, i.e. fresh oyster mushrooms that are directly taken from the home cultivation of mushrooms. The mushroom was harvested then marketed to individual stalls and vegetable traders sell out there in Kampung Suka Jadi. Else, if there is the excess stock of mushroom that cannot 
be absorbed by the stall and vegetable merchants, members of other groups and people will always buy it at a price equal to the market. In other words, there is no mushroom left although exceeding the existing marketing stock, due to social capital in the community. Third, on the activities of the trash bank, there is follow-up action in terms of processing waste recycling into a wide variety of crafts. Any time there is a mechanism of input raw materials from this event that is named as TAMPAH TUKIDI, i.e. waste savings to grow toddler and baby. TAMPAH TUKIDI is a mechanism that allows participants an integrated health service every third Wednesday selling garbage to the group. Then exchanged in the form of the ministry of health and the food and medicines for free. Nevertheless, this raw material input mechanism is still not running, as it should, this is due to the presence of scavengers and junk jobber touring the village.

Products produced in this activity is still not smooth as the other two activities. This is due to his difficult market access due to the absence of a suitable sales partner. Yet the issue does not become an obstacle that cannot be solved. The members of the group and its relatives, also always buy products in this activity, such as handbags, purses, necklaces, and more. Nevertheless, it is also undeniable that the activities of the trash bank and the processing craft of waste recycling is still many homework must be completed soon for the sake of continuity and sustainability.

Based on three kind of activities that have been described above, then we can conclude that although there is a constraint in each activities, the community is always present to help them. Not only in terms of purchase of the product, but also of the willingness of time, effort, and their minds. Even though with utilizing social network owned by the communities themselves. It is, in fact, undeniable that the program is viewed from three sorts of activities can be successful. However, the utilization of the social capital in the sustainability of this program make it a foundation in the framework of the achievement of healthy funds independently.

\section{The Role of Stakeholders Cooperation}

In terms of work through the Program Pendampingan Posyandu Pelawi Menuju Posyandu Mandiri will be incompleted if we do not discuss the role of stakeholders. As the concept of welfare pluralism, a variety actor ever to participate in the program increased the welfare of society. In this concept, the country is not the only one actor who implement the program increased the welfare of society, but also the other sectors, namely: public sector, private sector, mutual aid, voluntary sector, and informal sector (Spicker, 1995). The public sector refers to the responsibility and liability of the State as a provider of the citizen well-being purpose. Private sector refers to the role in the achievement of well-being communities through CSR. The role of the community in terms of mutual aid, voluntary sector, and informal sectors.

In any sector that definitely has its advantages and drawbacks, for that muchneeded space cooperation among stakeholders through its contribution to cover the shortfall. The cooperation between stakeholders becomes an inevitability that is preceded by an open system development by the government, which must then be followed by the private sector and the community to develop an open system (Krisdyatmiko, 2012, p. 130).

This section will describe how the cooperation and the role of stakeholders in order to reach the goals of program. These Stakeholders are composed of the Kampung Suka Jadi Government, PT. Pertamina EP Asset I Field Rantau, PT. Mopoli Raya, Mukim Balai, Sapta Jaya, and also community itself.

First, the Kampung Suka Jadi Government has a role in financial support, social support, advocacy, and monitoring and evaluation. In financial support, the govern- 
ment has disbursed funds amounting to IDR 13.3 million, -annually starting in 2015. These funds are intended for the empowerment of Posyandu Pelawi and Child Development and Family (BKB), including any funds that allocated for the sustainability of this program on its own. The form of such expenditure is on for cadres's salary of Posyandu Pelawi and Child Development and Family (BKB) who are members of the target group of the program with the IDR 50.000 per month per person. It is with the procurement of facilities supporting programs and mentoring programs, such as raw materials, tools and equipment activities programs, and various other needs on the activities of the principal public health service integrated Posyandu Pelawi.

In terms of advocacy, the government always accepted all complaint, suggestions, and criticism related with the implement- ation of program. This was compiled by the government's advocacy then be conveyed to the parties concerned. The implementation of advocacy more have done informally, i.e. not through formal monthly meetings as forums and so on. In terms of monitoring and evaluation, the government often present and participate in every activity that exists in this program. At the same time, the government also conducts monitoring and evaluation which is suddenly and without any structure. While it is the presence of the government in the activities judged very helpfully for the sustainability of the program, especially in relation to the social support received by the target group.

Second, the role of PT. Pertamina EP Asset I Field Rantau within mentoring Posyandu Pelawi until the implementation of the program may be traced in the following table 3 .

Table 3

PT. Pertamina EP Asset I Field Rantau Assistance for Posyandu Pelawi

\begin{tabular}{|c|c|c|c|}
\hline Year & Description & Mentor & Benefici-aries \\
\hline 2013 & $\begin{array}{l}\text { Capacity building through a combination of } \\
\text { training on the health, tools assistance health, } \\
\text { uniforms aid posyandu cadres }\end{array}$ & $\begin{array}{l}\text { NGOs Bina } \\
\text { Insan Mandiri }\end{array}$ & All members \\
\hline 2014 & Monitoring Posyandu Activities & $\begin{array}{l}\text { CSR Staff PT. } \\
\text { Pertamina EP } \\
\text { Asset I Field } \\
\text { Rantau }\end{array}$ & All members \\
\hline 2015 & $\begin{array}{l}\text { Capacity building through a combination of } \\
\text { training about the relation to health, health tools } \\
\text { assistance }\end{array}$ & NGOs LP2K & All members \\
\hline 2016 & $\begin{array}{l}\text { Self-awareness survey, formulating assistance } \\
\text { program in 2016, training posyandu cadres, the } \\
\text { formation of trash bank, strengthen the trash } \\
\text { bank, donation advocates Posyandu activities }\end{array}$ & $\begin{array}{l}\text { NGOs LP2K } \\
\text { and CDO PT. } \\
\text { Perta- mina EP } \\
\text { Asset I Field } \\
\text { Rantau }\end{array}$ & All members \\
\hline 2017 & $\begin{array}{l}\text { Facilitation game education children, facilitation } \\
\text { instrument and materials for an increase in } \\
\text { making the craft of recycling garbage, pro- } \\
\text { curement medical equipment, improvement and } \\
\text { strengthening facilities medicinal plants families, } \\
\text { making corner read posyandu, making corner } \\
\text { breastfeeding, training and practice making a } \\
\text { drink herbs, development of mushroom house, }\end{array}$ & $\begin{array}{l}\text { CDO PT. Perta- } \\
\text { mina EP Asset } \\
\text { I Field Rantau }\end{array}$ & All members \\
\hline
\end{tabular}


training mushroom cultivation, training making

craft with recycling garbage, class mother

toddlers, class mother toddlers

Source: The results of CSR Division PT. Pertamina EP Asset I Field Rantau, 2017.

Based on table 3, the role of PT. Pertamina EP Asset I Field Rantau in terms of improving the quality of cadres to the implementation of the program has been implemented since the year 2013. However, the implementation of a program that is focused on the acquisition of healthy new Posyandu Mandiri funds starting in 2017. A series of activities aimed to realize improved strata Posyandu Pelawi became independent, i.e. an increase in the quality and quantity of cadres, strengthening the institutional, and obtaining funds healthy.

In addition, PT. Mopoli Raya who was the private sector that operates in the territory of Kampung Suka Jadi ever participate in the achievement of the objectives of the program. This is evidenced by the role he gave land 1.7 Ha to Kampung Suka Jadi. The land will be managed and utilized by the government to build the infrastructure of the Kampung Suka Jadi that is the office of Posyandu Pelawi, parks, and public spaces. Given the current, Posyandu Pelawi has no office and still occupy the space hall meetings village. Currently, infrastructure development is still in progress. Funds used in such development ever come from the budget of Kampung Suka Jadi Income and Expenditure of Kampung (APBK) funds, the CSR of PT. Mopoli Raya, PT Pertamina EP Asset I Field Rantau, and elements of community itself. With the presence of major infrastructure and supporting Pelawi Posyandu, it will increasingly facilitate the achievement program purpose i.e. selfcontained Posyandu Pelawi. Given the existence of such infrastructure is one of the criteria of Posyandu Mandiri strata in addition to obtaining funds healthy.

Third, of the community, the cooperation can be seen from the role of Mukim Balai, Sapta Jaya, Dasa Wisma Group, and the community itself in general. The role of the program's existence in the Mukim Balai is not associated directly with the program. Except the role can be said to be important as well especially in its function as the implementing customs and mediator of the conflict in the region of Mukim Balai. Then through the role of Sapta Jaya as an Alliance of seven villages that function in the delivery of the aspirations of the people. For example, in 2015-2016, there is a demand from the community will help CSR has been promised by one of the companies that operate in the region. Then the Sapta Jaya gathers and conveys the aspirations to the parties concerned.

However, such aspirations are not well received by the parties concerned. It then triggers the onset of conflict between the community and the company. The priest eventually as the Head of Mukim, mediate both sides in order to deliberate on the related way out these problems. After several meetings done, finally agreed on a deal between the two sides, namely the granting of assistance for the repair of the driveway access to the Kampung Suka Jadi and grant land covering an area of $1.7 \mathrm{Ha}$. The core of the case is the clarification that it is the role of the Mukim Balai and Sapta Jaya tend more to the realm of politics, i.e. people's aspirations advocacy and the mediation of the conflict. Indeed, not associated directly with the program, but the role is one of the 'entrance' to the achievement of the objectives of the program.

The Dasa Wisma Group presumably have been clear, as it has been explained in part before. The Dasa Wisma Group role in financial assistance through the mechanism of Posyandu Pelawi monthly dues amounting to IDR 1.000 per house. These funds are then used for the provision of public health services activities, integrated procurement service health facilities, and assistance for the 
sustainability of existing activities in the Program. On the overall community of Kampung Suka Jadi, the principle of reciprocity and volunteerism have always been the spirit in each of the existing activities in the village also any included activities on this program. The community always help a group of Posyandu Pelawi in terms of implementation, the marketing of products, and the function as a social safety net when the activities and the products are having a constraint.

\section{CONCLUSION, LIMITATION, AND SUGGESTION}

The Program Pendampingan Posyandu Pelawi Menuju Posyandu Mandiri indeed cannot yet be said to be successful. Following the acquisition of healthy funds independently as a goal of the new program was implemented for one year. However, the description of the implementation programs process that may have presented important to consider, by both the government, the private sector, and community in general. Although the program appearance was initiated by PT. Pertamina EP Asset I Field Rantau, social capital has been put to good use as a foundation of making the sustainability of the program. Also, there is any disclosure of other stakeholders in support of the achievement of the program purpose.

However, this program is not free from criticism. The social capital that used in the program tend to be exaggerated. When the use of excessive social capital persists, it will make the Posyandu Pelawi become dependent which contrary to the program purpose. Even though, as a preliminary, social support from various parties is very necessary for the program. Also, the goal efforts of achievement program from stakeholders are still spontaneity. Although the assistance provided within the purpose achievement efforts of the program, it is still not specifically.

Therefore, the program implementation is required for improvements, especially in terms of the input mechanism and processing bank trash activity in term of waste recycling into a wide variety of handicrafts. Also, the mechanism of product marketing mushrooms and garbage so that the bank can be absorbed by the market, which is not only relying on the community as a social safety net. Furthermore, any required binding between actors formally in the frame of the multi-stakeholder forum. Moreover, the achievement efforts of the program purposes will be more measured and well-planned. In addition, the forum will be very useful not only for this program but for other programs as well.

As a recommendation for a company or private sector which is or will be carrying out CSR program may need to be considered in identifying the issues, related to mature potential, and opportunities that exist at the location of the candidate's program. Therefore, the program is really done well in compliance issues, potential, and opportunities that exist. The utilization of the power of social capital of the community in Kampung Suka Jadi and the role of stakeholders in the program presumably are one of example of how placement the CSR program that correspond to the problem, the potential, and the opportunities that exist in there.

\section{ACKNOWLEDGEMENT}

This article has modified from the research result of Satisfaction Community Index and Monitoring and Evaluation CSR Program within PT. Pertamina EP Asset I Field Rantau which was engaged by Social Development and Welfare Department, Universitas Gadjah Mada in 2018. I would like to thank for Social Development and Welfare Department, Universitas Gadjah Mada who gave me an opportunity for contributed as a research assistant and within giving me a space to carry out a personal research. I also thankful for $\mathrm{Mr}$. Susetiawan who inspired me to apply for civil society concept into understanding CSR program, Mr. Nurhadi, Mr. Yuda, Mr. 
Pinurba, and Mr. Mahaswa who gave me another opinion and helped me within working on this article too. For special remarks, I dedicate this article to my parents, my sister, Mrs. Nadia Kaulika, who always supported and gave me motivation for my research progress

\section{REFERENCES}

Allinson, R., K. Izsak, and E. Grinience. 2012. Catalysing Innovation in the Knowledge Triangle: Practices from the EIT Knowledge and Innovation Communities. Brussels: European Institute of Innovation and Technology - Technopols Group.

Bowen, J. R. 1986. On the Political Construction of Tradition: Gotong-royong in Indonesia. The Journal of Asian Studies 45(3): 545-561.

Cohen, S. and L. Prusak. 2001. In Good Company: How Social Capital Makes Organization Work. Harvard Business Press. London.

Coleman, J. 1999. Social Capital in the Creation of Human Capital. Harvard Business Press. Cambridge.

Field, J. 2010. Social Capital. Routledge. London.

Freeman, E. R. 1984. Strategic Management: A Stakeholder Approach. Pitman Publishing. Boston.

Gupta, S. and D. Ogden. 2009. To Buy or not to Buy? A Social Dilemma Perspective on Green Buying. Journal of Consumer Marketing 26(6): 376-291.

Hair, J., H. Arthur, S. Phillip, and P. Mike. 2007. Research Methods for Business. John Wiley and Sons Ltd. Cichester.

Hensen, E. and P. Ndhlovu. 2011. Conceptualising Corporate Social Responsibility (CSR) and Corporate Social Investment (CSI): The South African Context. Social Responsibility Journal 7(3): 332-346.

Jin, H. and J. Shriar. 2013. Linking Environmental Citizenship and Civic Engagement to Public Trust and Environmental Sacrifice in the Asian Context. Journal of Environmental Policy and Governance 23(4): 259-273.

Jones, B., R. Bowd, and R. Tench. 2009. Corporate Irresponsibility and Corporate Social Responsibility: Competing Realities. Social Responsibility Journal.

Kania, J. and M. Kramer. 2013. Collective impact. Retrieved from Stanford Social Innovation Review website: https:// ssir.org/articles/entry/collective_impact.

Krisdyatmiko. 2012. Kemitraan PemerintahSwasta-Masyarakat dalam Bingkai Forum Multi-Stakeholders Corporate Social Responsibility (MSH-CSR). In Susetiawan (Ed.), Corporate Social Responsibility: Komitmen untuk Pemberdayaan Masyarakat (127-171). Azzagrafika. Yogyakarta.

Kusakabe, E. 2012. Social Capital Networks for Achieving Sustainable Development. Local Environment: The International Journal of Justice and Sustainability 17(10): 1043-1062.

Melo, T. and A. Garrido-Morgado. 2011. Corporate Reputation: A Combination of Social Responsibility and Industry. Corporate Social Responsibility and Environmental Management 19(1): 11-31.

Moleong, L. J. 2007. Metode Penelitian Kualitatif. Remaja Rosda Karya. Bandung.

Mortensen, M. 2012. Through the looking glass: Reflected knowledge and trust in global collaboration (No. 2012/03/OB).

Putnam, R. D. 1993. Makin Democracy Work: Civic Traditions in Modern Italy. Princeton University Press. New Jersey.

Putnam, R. D. 2000. Bowling Alone: The Collapse and Revival of American Community. Simon and Schuster. New York.

Ramasamy, B. and M. Yeung. 2010. The Determinants of Foreign Direct Investment in Services. World Economy 33(4): 573-596.

Seavoy, R. E. 1977. Social Restraint on Food Production in Indonesian Subsistence Culture. Journal of Southeast Asian Studies 8(1): 15-30.

Sugiyono. 2012. Metode Penelitian Kuantitatif, Kualitatif, dan RandD. Alfabeta. Bandung. 
Suharto, E. 2007. Pekerjaan Sosial di Dunia Industri: Memperkuat Tanggung Jawab Sosial Perusahaan. Refika Aditama. Bandung.

Suharto, E. 2008. Corporate Social Responsibility: Strategy Management and Leadership. Inti Pesan. Jakarta.

Sumarto, M. 2017. Welfare Regime Change in Developing Countries: Evidence from Indonesia. Journal of Social Policy and Administration 51(6): 940-959.

Susetiawan. 2012. Implementasi CSR dalam Arena Civil Society: Antara Idealisme dan Realitas. In Susetiawan (Ed.), Corporate Social Responsibility: Komitmen untuk Pemberdayaan Masyarakat (pp. 330). Azzagrafika. Yogyakarta.

Tennyson, A. 1998. The Works of Alfred Lord Tennyson. Word-sworth Editions Ltd. Hertfordshire, UK.
Thoyre, A. 2011. Social capital as a facilitator of pro-environmental actions in the USA: A prelimenary examination of mechanisms. Local Environment: The International Journal of Justice and Sustainability 16(1): 37-49.

Wibisono, Y. 2007. Membedah Konsep dan Aplikasi Corporate Social Responsibility (Fascho Pub). Gresik.

Woolcock, M. and D. Narayan. 2000. Social Capital: Implications for Development Theory, Research, and Policy. The World Bank Research Observer 15(2): 25-249.

Yuda, T. K. 2016. Memaknai Ulang Corporate Social Responsibility: Upaya Mewujudkan Fair Responsibility. Jurnal Ilmu Sosial Dan Ilmu Politik 29(3): 200217. 